\title{
Mapping and Assessment of Volcanic Hazards Related to the Ignimbritic Eruption by AMS in Bambouto Volcano (Cameroon Volcanic Line)
}

\author{
M. Gountié Dedzo ${ }^{*}, 1$, P. Kamgang ${ }^{2}$, E. Njonfang ${ }^{3}$, G. Zangmo Tefogoum ${ }^{4}$, A. Kagou Dongmo ${ }^{5}$ and \\ D.G. Nkouathio 5
}

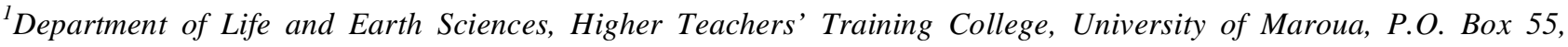 \\ Maroua, Cameroon \\ ${ }^{2}$ Department of Earth Sciences, University of Yaoundé I, P.O. Box 812, Yaoundé, Cameroon \\ ${ }^{3}$ Laboratory of Geology, Higher Teachers' Training College, University of Yaoundé I, Cameroon, P.O. Box 47, Yaoundé \\ I, Cameroon \\ ${ }^{4}$ Higher Institute of Sahel, University of Maroua, P.O. Box 45, Maroua, Cameroon \\ ${ }^{5}$ Department of Earth Sciences, University of Dschang, P.O. Box 67, Dschang, Cameroon
}

\begin{abstract}
Pyroclastic deposits constitute major components of explosive volcanic activity. To help improve the safety of the population faced with natural disasters, a study is carried out at Bambouto volcano with a view to map potential hazards related to pyroclastic flows. The Bambouto volcano is indeed considered to be still active since the recent discovery of Quaternary basalts $(0.5 \mathrm{Ma})$ at Totap, a locality situated near the Bambouto Caldera. This discovery has led to reclassify Mount Bambouto among active volcanoes of Cameroon and, therefore, considered as potentially dangerous. The dangerousness of this volcano is accentuated by the presence of ignimbrites that are witnesses of ancient pyroclastic flows. Because a map of volcanic hazards is non-existent on the volcano, anisotropy of magnetic susceptibility (AMS) is the method used in this paper to characterize magnetic fabrics and provides an estimate of flow direction of each ignimbrite sheet (represented by massive lapilli tuff and massive lithic breccia facies). Inferred transport directions based on the AMS data and field indicators show that Bambouto Caldera is the source of main pyroclastic deposits of Mount Bambouto. These results have enabled us to produce a new hazard map related to potential future pyroclastic flows.
\end{abstract}

Keywords: AMS, Bambouto, Cameroon, hazard mapping, ignimbrites.

\section{INTRODUCTION AND GEOLOGICAL SETTING}

The Cameroon Volcanic Line (CVL, Fig. 1a, b), a 1600 $\mathrm{km}$ long mega-shear zone in central Africa, shows a characteristic alignment of continental and oceanic volcanoes, plutonic complexes and grabens. Bambouto volcano $\left(500 \mathrm{~km}^{2}\right)$ is situated in the continental part of the CVL with Mount Mélétan $(2740 \mathrm{~m})$ as its highest point. It extends between longitudes $9^{\circ} 55^{\prime}$ and $10^{\circ} 15^{\prime}$ east and latitudes $05^{\circ} 25^{\prime}$ and $05^{\circ} 50^{\prime}$ north and bears a collapsed caldera ( $8 \times 13 \mathrm{~km}$; Fig. 2) at the summit. It is one of numerous volcanic vents (six islands and five central volcanoes: Mounts Cameroon, Manengouba, Bambouto, Bamenda and $\mathrm{Oku}$ ) along a 1600-km-long segment of the CVL. This volcano is considered to be still active since the recent discovery of Quaternary basalt $(0.48 \pm 0.014 \mathrm{Ma}$; [1] $)$ at Totap near the Bambouto Caldera. Elliptical in shape and oriented roughly southwest-northeast, its long axis is around $45-50 \mathrm{~km}$ and its short axis $20-25 \mathrm{~km}$. The towns of Dschang and Mbouda (241,000 inhabitants), as well as a number of

*Address correspondence to this author at the Department of Life and Earth Sciences, Higher Teachers' Training College, University of Maroua, P.O. Box 55, Maroua, Cameroon; Tel: (237) 750885 86;

E-mail: merlin.gountie@gmail.com villages, are located on the flanks of this large volcano (Fig. 3).

Mount Bambouto is probably a volcanic horst fed mainly by fissures, most with a NE-SW orientation. It is made up of volcanic products dated from $21.12 \pm 0.45$ Ma to $0.48 \pm$ $0.014 \mathrm{Ma}$, and comprises basalts, trachytes, phonolites, rhyolite and ignimbritic deposits that form various facies [2]. The volcanological story of the Mount Bambouto can be subdivided into three main stages $[1,3]$ : The $1^{\text {st }}$ stage, ca. 21 $\mathrm{Ma}$, was devoted to the building of a primitive shield volcano with alkaline basalts. The $2^{\text {nd }}$ stage, between 18.5 and 15.3 Ma, corresponds to the formation of the caldera in response to the large-volume eruptions of rhyolitic and trachytic magmas from a large, evolved, sub-volcanic magma reservoir and the formation of extensive ignimbrite sheets. The $3^{\text {rd }}$ stage renewed activity with effusive basanite to mugearite eruptions between 15.1 and $4.5 \mathrm{Ma}$, together with post-caldera extrusions of trachytes between 15 and 8.8 $\mathrm{Ma}$, and of phonolites between 12.9 and 5.2 Ma. Basaltic $(0.48 \mathrm{Ma})$ effusive activity of Totap could indicate the beginning of a fourth stage.

Mount Bambouto has has been subjected to several catastrophic events of different origins over the past few years [4]: meteorological events such as landslides and rock 


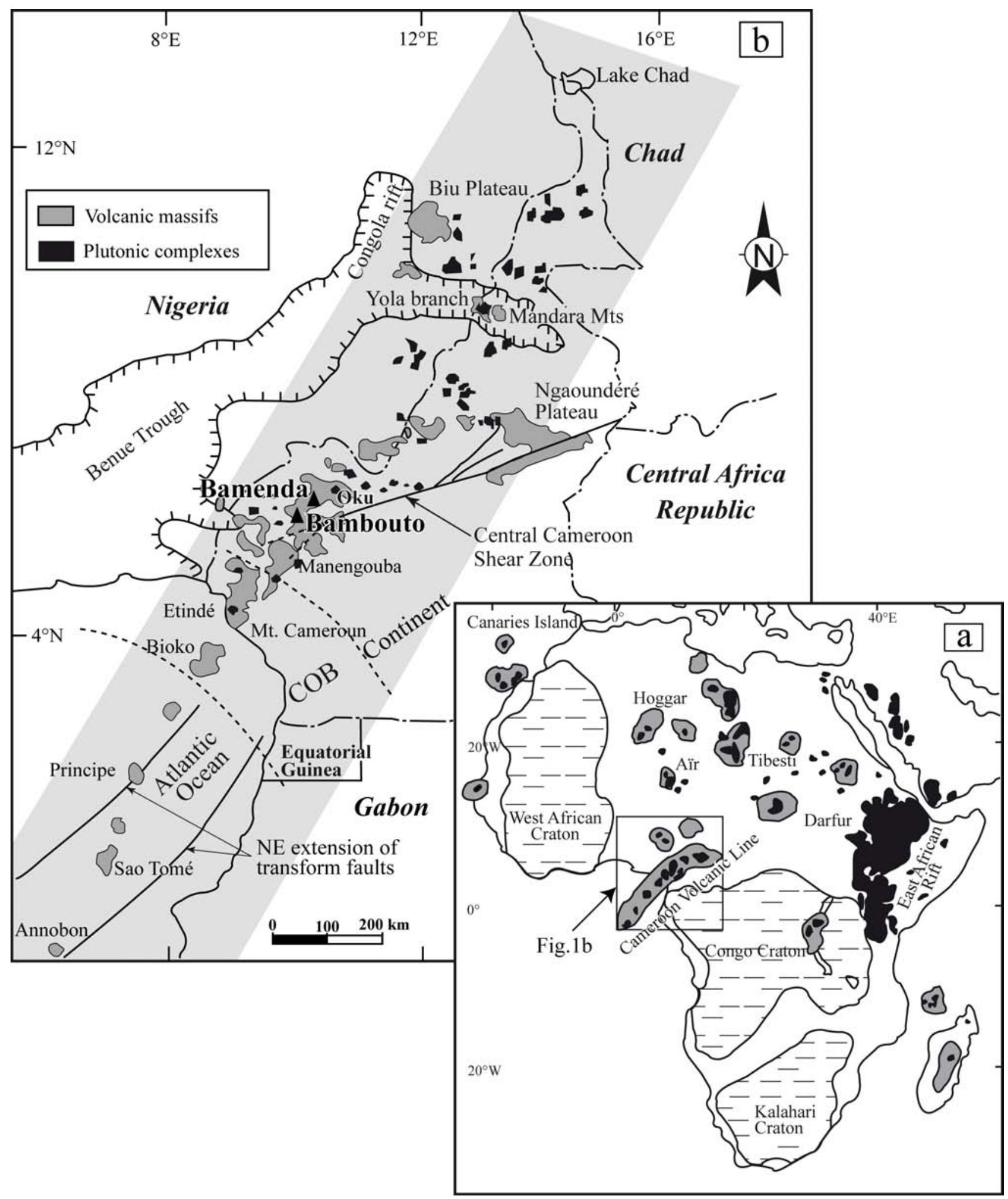

Fig. (1). a) Location map of the Cameroon Volcanic Line (CVL). b) The main volcanic centres of the CVL with the plutonic complexes. Central Cameroon Shear Zone [33], COB (Continental Ocean Boundary) and fracture zones [34, 35] are represented; dashed lines are limits between the CVL segments: ocean, $\mathrm{COB}$ and continent.

falls; and anthropogenic events such as bushfires, tribal wars, and deforestation. Soil fertility on the volcano has fostered a significant population growth (more than 450,000 people) in this area. This population is supported by agropastoral and economic activities within the caldera and on the flanks of the volcano estimated at about \$US 2.1 billion. 


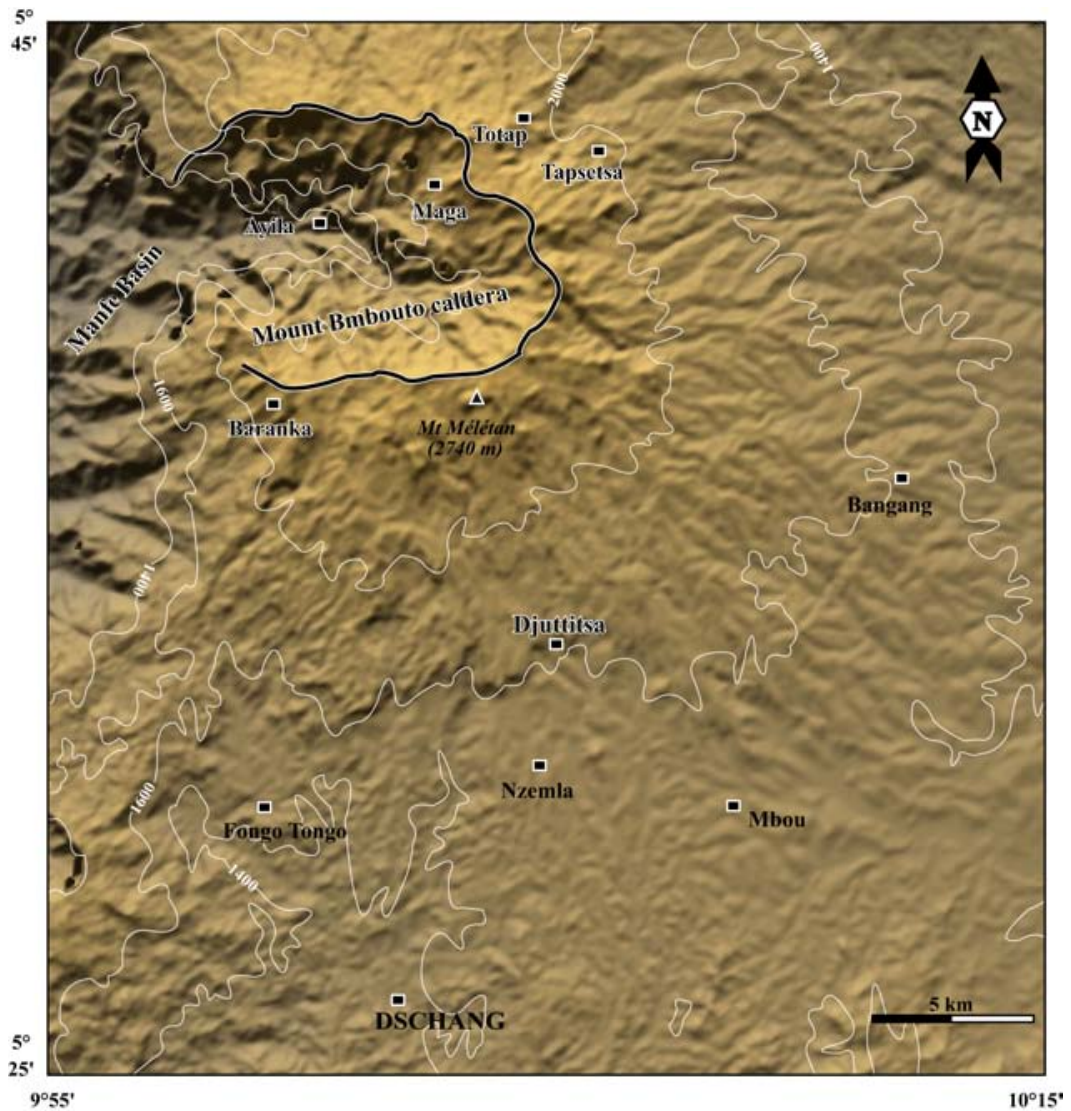

Fig. (2). Digital elevation model (DEM) of Mount Bambouto and the close surroundings: Shuttle Radar Topography Mission (SRTM, NASA).

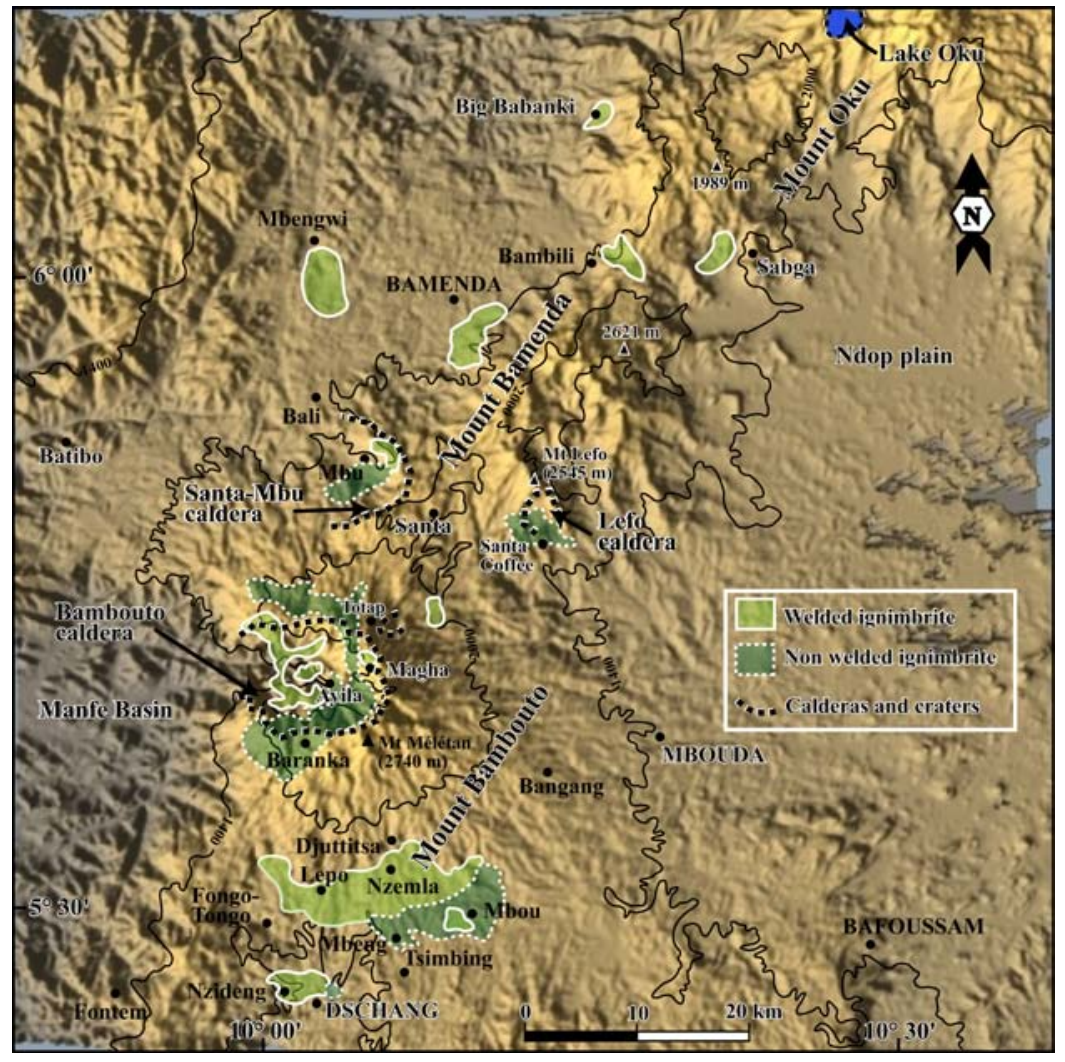

Fig. (3). DEM of Mount Bambouto and the close surroundings presenting the ignimbritic outcrops. 


\section{AIM OF STUDY}

In order to map the volcanic hazards related to large ignimbritic eruptions, which are the most disastrous in terms of possible volcanic processes in this region, a research method known as anisotropy of magnetic susceptibility (AMS) has been used to determine flow directions in ancient ignimbrites which are visually nearly isotropic in most outcrops. Magnetic fabrics of ignimbrites help us to determine palaeoflow directions of pyroclastic density currents, to then reassemble discontinuous deposits into their original ignimbrite sheets, and to identify their source. Such reconstructions allow us to propose future potential ignimbritic eruption scenarios.

\section{AREAL DISTRIBUTION AND PETROGRAPHY OF IGNIMBRITES}

Ignimbrites are rare in the CVL and mainly observed in the central part of this volcanic chain; they are concentrated especially in Mount Bambouto and its NE extension (Mount Bamenda) (Fig. 3). These deposits cover $20 \%\left(\approx 135 \mathrm{~km}^{2}\right)$ of the Bambouto massif with thicknesses ranging from 30 to $120 \mathrm{~m}$. The volume of these pyroclastic deposits, estimated at $13.5 \mathrm{~km}^{3}$, is probably much larger because these formations are covered by younger basalts in the southern part of the massif. In the lower zone (1400-1600 m), they lay on a metamorphic basement, while in the upper zone $(>2000$ $\mathrm{m})$, they cover trachytic lavas. Following the new classification of pyroclastic deposits [5], the ignimbrite facies cropping out on this massif are characterized by massive, welded and non-welded lapilli tuff (mlT) and lithic breccia $(\mathrm{mlBr})$.

The southernmost ignimbrites of Dschang $\left(9 \mathrm{~km}^{2} ; 18.1\right.$ Ma, [6]) outcrop in sheets in the Menoua Valley (Fig. 4a) and are overlain in places by an aphyric basaltic flow (Figs. 5, 6a) (12.52 Ma; [7]). They are intersected in the west by a dyke of phonolite (6.61 Ma; [7]). The ignimbrites of Mbeng, Mbou, Lepo, Nzemla I and Nzemla II are the main ignimbrite outcrops $\left(82 \mathrm{~km}^{2}\right)$ of east of Fongo-Tongo (Figs. 5, 6b-d) and are covered in places with basalts (14.08 Ma; [7]). The ignimbrites of Baranka $\left(44 \mathrm{~km}^{2}\right)$ outcrop at the summit area of the volcano and discontinuously cover the south-western rim and the bottom of the Bambouto Caldera (Fig. 4e, f, 5). Their thickness is difficult to estimate because of steep relief and dense vegetation. Several ages of ignimbrites are indicated by interbedded trachytic and basaltic lava flows (Fig. 6e). All of these ignimbrite units are bracketed between 18.1 and $12.5 \mathrm{Ma}$ representing several different eruptions.

The welded parts of all these deposits consist of one simple cooling unit. This cooling unit may include one to two flow units, which are represented by a dark grey unit (DGU), a light grey unit (LGU) and a whitish unit (WU) (Fig. 6) [2]. The lower parts of welded ignimbrites have an eutaxitic texture characterized by deformed and devitrified fiammes (5-20\%) with a preferentially oriented direction (Fig. 4b). This suggests that the pyroclastic flow moved roughly toward azimuths $200-215^{\circ}$ (direction of Menoua Valley) at Dschang and $349-356^{\circ}$ at Lepo. In all the ignimbrite sheets, the matrix is devitrified and bears numerous lithic fragments $(0.3 \times 0.4 \mathrm{~cm}$ to $1.2 \times 1.6 \mathrm{~cm}$,
$10-35 \%)$, most of them displaying a trachytic texture. Lithic fragments and inclusions include: rhyolites, granitic basement, obsidian, accretionnary lapilli, scoria (primarily at Mbou Fig. 4c, d) and fragments of carbonised wood. The devitrified matrix (with non-devitrified glass shards at Mbou) is made of mostly fragmented minerals represented by alkali feldspar (sanidine and anorthoclase; 10-35\%), quartz $(3-5 \%)$, plagioclase $(1-3 \%)$, oxides (1-3\%), biotite $(1-$ $3 \%)$ and clinopyroxene $(1 \%)$. The abundance of fragmented minerals (40-85\%), accretionary lapilli and co-ignimbritic breccias in the caldera and its surrounding areas reflects the highly explosive character of eruptions that preceded the emplacement of these rocks [8]. These particularities of the ignimbritic eruption increase the level of risk in the Bambouto massif. Subvertical elutriation pipes (up to $1.2 \mathrm{~cm}$ in diameter) are common in the middle part and at the top of deposits of the WU (Nzemla II) and of the DGU (Mbeng) indicating the release of fluid phase after deposition.

\section{SAMPLING METHOD AND AMS MEASUREMENTS}

Magnetic susceptibility $\mathrm{K}(\mathrm{K}=\mathrm{M} / \mathrm{H}$, in SI units $)$ expresses the ability of a body to acquire a magnetization (M) when subjected to an inducing magnetic field $(\mathrm{H})$. Iron is the main element responsible for the magnetization. Anisotropy of low field magnetic susceptibility is a versatile petrofabric tool. For magnetite, AMS primarily defines grain-shape anisotropy; for other minerals, AMS expresses crystallographic control on magnetic properties [9]. Thus, we may infer the orientation-distribution of a dominant mineral from the AMS of a rock. AMS principal directions can record current directions from sediment, flow-directions from magma and pyroclastic deposits. In this study, AMS is applied on ignimbrites with a view to reconstitute palaeoflow directions of pyroclastic current. All measurements were made in GET (Géosciences Environnement Toulouse) laboratory at Paul Sabatier University in Toulouse, France. Sampling of the Bambouto ignimbrites was performed on 31 stations (244 core samples) (Fig. 5) using a portable, gasoline-powered drill-machine with a non-magnetic diamond-tipped drill bit. Stations were distributed somewhat homogeneously over each ignimbrite sheet. At each site, a total of 6-10 oriented cores were collected in an area covering approximately 5 to $10 \mathrm{~m}^{2}$. Samples were then oriented (azimuth/dip) using magnetic compass and carefully numbered. In laboratory, each core sample was cut into $22 \mathrm{x}$ $25 \mathrm{~mm}$ cylinder specimens, using a diamond tipped, nonmagnetic saw blade. Up to four specimens per sample were obtained, hence a total of 661 specimens. AMS measurements were performed on a Kappabridge susceptometer (KLY-3S, Agico, Czech Republic; operating at low alternating field $\left(4 \times 10^{-4} \mathrm{~T}\right.$ at $\left.920 \mathrm{~Hz}\right)$ with a sensitivity of about $2 \times 10^{-7} \mathrm{SI}$, allowing anisotropy discrimination below $0.2 \%$ over a wide range of susceptibility. This method measures the orientation of the magnetic carriers (minerals) in a rock which help to generate ancient flow directions. AMS measurement of one rock specimen results in an ellipsoid of magnetic susceptibility defined by the length and orientation of its three orthogonal axes, $K_{1} \geq K_{2} \geq K_{3}$. The long axis $K_{1}$ (maximum susceptibility) defines the magnetic lineation, meanwhile the short axis $\mathrm{K}_{3}$ (minimum susceptibility) is the foliation pole, 

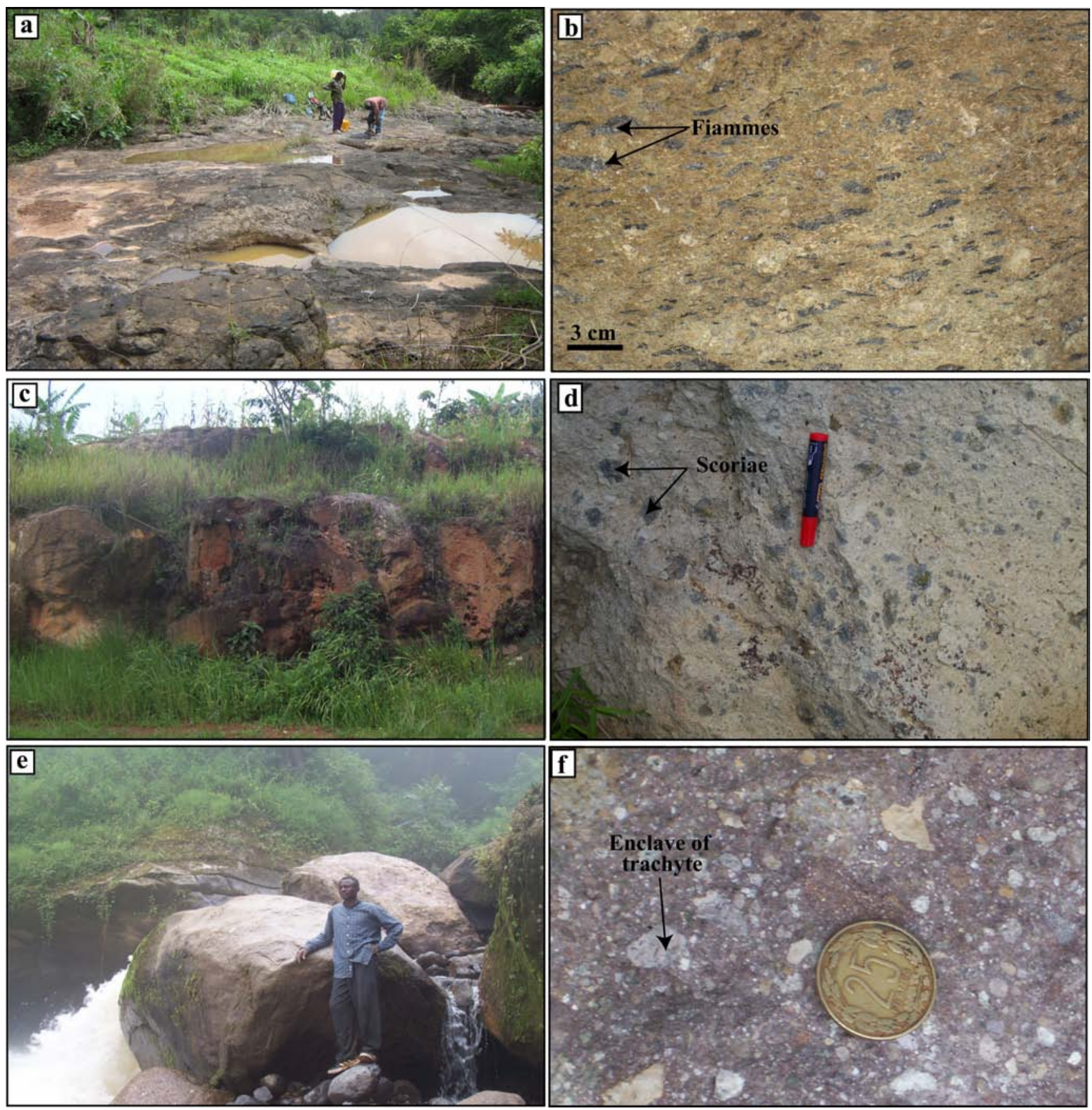

Fig. (4). a) Ignimbrite of Dschang outcrop in Menoua River. b) Detail of Dschang ignimbrite showing preferentially oriented fiammes. c) Roadcut with ignimbrite outcrop in Mbou locality. d) Presence of multiple enclaves of scoriae in Mbou ignimbrite. e) Ignimbrite outcrop in the dregs of Baranka Caldera. f) Detail of Baranka ignimbrites showing multiples enclaves of trachytes.

i.e. the normal to the plane of magnetic foliation; $K_{2}$ is the mean susceptibility. The mean magnetic susceptibility $(\mathrm{Km})$ is the arithmetic mean of the lengths of the principal axes $(\mathrm{Km}=[\mathrm{K} 1+\mathrm{K} 2+\mathrm{K} 3] / 3)$. The technique also quantifies the anisotropy percentage $(\mathrm{P} \%=[(\mathrm{K} 1 / \mathrm{K} 3)-1] \times 100)$. In addition, the linear $(\mathrm{L} \%=[(\mathrm{K} 1 / \mathrm{K} 2)-1] \times 100)$ and planar $(\mathrm{F}=[(\mathrm{K} 2 / \mathrm{K} 3)-1] \times 100)$ anisotropies are also provided. The shape of the susceptibility ellipsoid is characterized by the $\mathrm{T}$ parameter with $\mathrm{T}=\left(2 \ln \mathrm{K}_{2}-\ln \mathrm{K}_{1}-\ln \mathrm{K}_{3}\right) /\left(\ln \mathrm{K}_{1}-\ln \mathrm{K}_{3}\right)$
[9] ranging from +1 for oblate ellipsoid to -1 for prolate ellipsoid. Triaxial ellipsoids are characterized by values between -0.5 and +0.5 .

Since the early work of Elwood [10], several studies have used AMS in an attempt to locate source vents of large ignimbrites. Some authors [11-13] compared AMS data from ignimbrites with field and petrographic observations and established that AMS provides an accurate and considerably quicker means of estimating the transport direction 


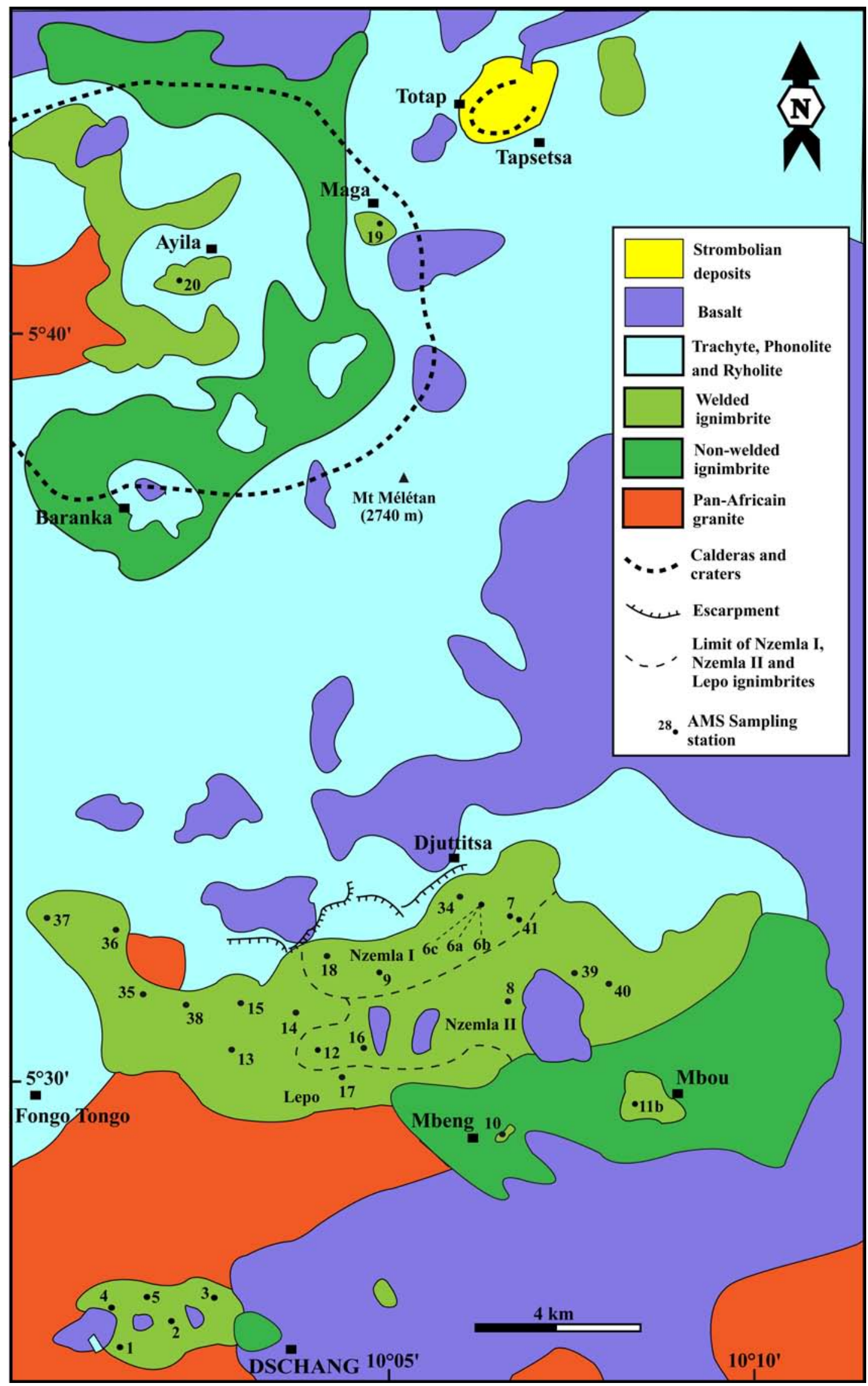

Fig. (5). Geologic sketch maps of Mount Bambouto showing the AMS sampled stations. 


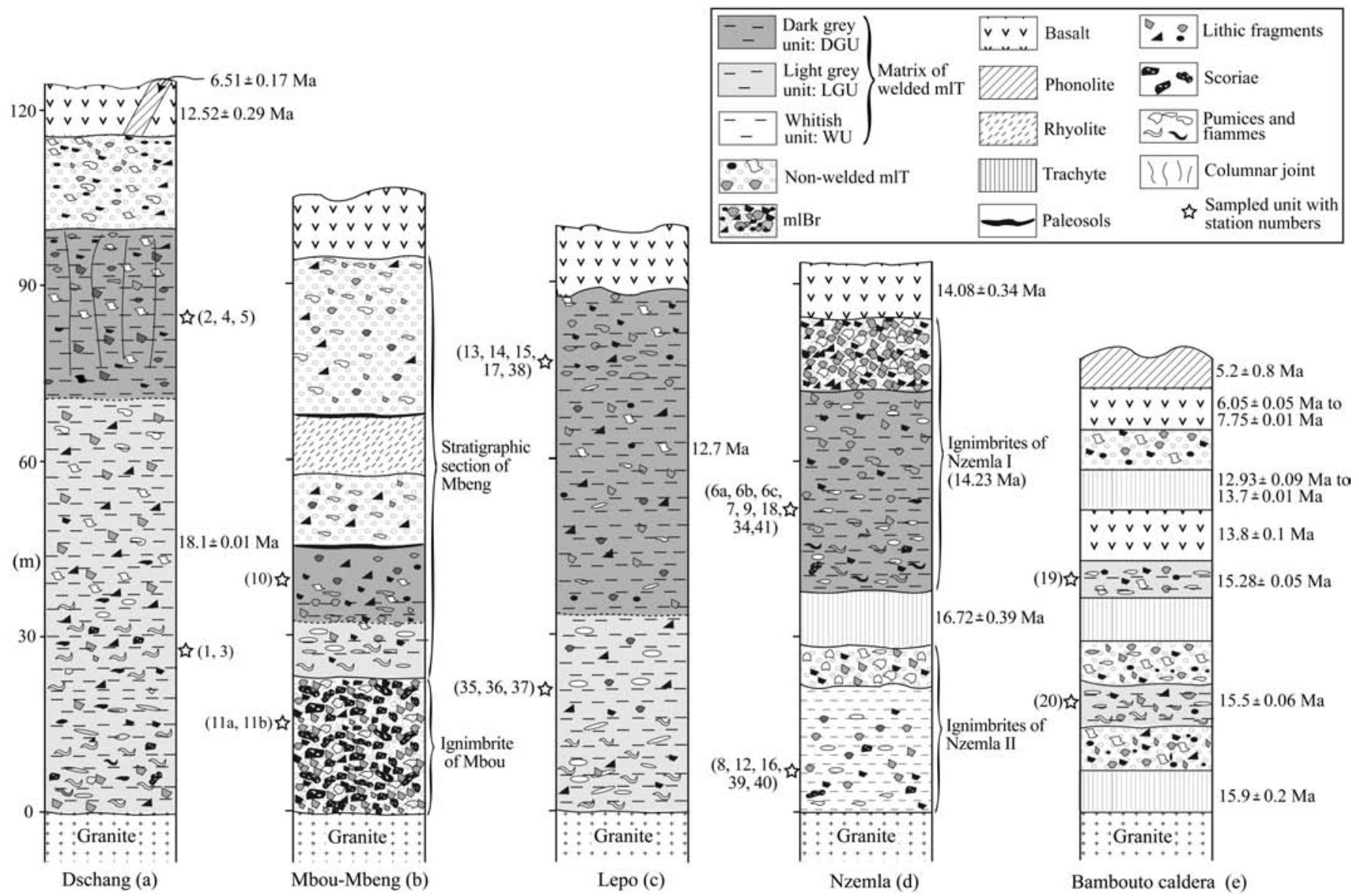

Fig. (6). Stratigraphic sections of the Mount Bambouto ignimbrites in some localities (modified from Gountié Dedzo et al., 2011[2]). The ages are from Youmen et al. (2005) [6], Nkouathio et al., 2008 [7], Gouhier et al. (1974) [36] and Tchoua (1973) [37].

of ignimbrites than procedures based on macroscopic inspection. It is demonstrated that the heterogeneous character of an ignimbrite does not seriously affect the AMS fabric, and that AMS provides a reasonable indication of the flow direction [14]. Results of previous AMS studies that have inferred flow patterns for ignimbrites suggest that the distribution and alignment of magnetic grains produces the anisotropic magnetic fabric $[10,11,14,15]$. The shape of the susceptibility ellipsoid of most rocks represents the preferred alignment of paramagnetic $(\mathrm{Km}<500 \mu \mathrm{SI})$ and ferromagnetic $(\mathrm{Km}>500 \mu \mathrm{SI})$ mineral grains within the rock $[10,16]$. Several magnetic studies of silicic rocks have shown that ferrimagnetic phases such as magnetite and maghemite, when present, dominate the magnetic susceptibility [17-19]. In the Bambouto ignimbrites, titanomagnetite, titanohematite, maghemite and goethite are the most common ferrimagnetic phases [2]. The remaining paramagnetic phases, predominantly $\mathrm{Fe}-\mathrm{Mg}$ silicates such as biotite and pyroxene contribute significantly less to the magnetic susceptibility. Large values of $\mathrm{Km}$ of these rocks (> $500 \mu \mathrm{SI}$ in $76 \%$ of the sites) are consistent with a dominance by ferrimagnetic phases [16]. Magnetic foliations and lineations in ignimbrites arise as a result of alignment of magnetic mineral grains parallel to the flow direction, and the rotation of slightly elongate to sub-equant magnetic grains so that their long dimension roughly parallels the flow direction $[10,11]$. Shear caused by translation of silicate minerals, ash particles, and pumice and lithic fragments produces a shape alignment related to the flow conditions (i.e., laminar, turbulent, rheomorphic). For a normal magnetic fabric, the mean magnetic foliation plane (defined by $K_{1}-K_{2}$ axes) is normal to the $K_{3}$ axis and approximates the flow plane. However, the magnetic foliation plane often differs in orientation (imbrication angle) relative to the flow plane $[10,11]$ and dips in a direction opposite to the flow direction. The imbrication dip direction is inferred to point towards the source area. The maximum axis $\left(K_{1}\right)$ is typically interpreted to be parallel to the flow direction and thus plunges towards the source [11]. The use of the $\mathrm{K}_{1}$ susceptibility axis alone as a proxy for flow direction is not always reliable $[11,13,20-22]$, and a different approach must be used to interpret the AMS data. The imbrication angle of the magnetic foliation plane, which equals the deviation of the $\mathrm{K}_{3}$ axes from the normal to the macroscopic flow plane, provides an alternative method to discern the flow direction of ignimbrite deposits [23, 24]. Application of the imbrication angle approach may result in an alternate interpretation of the flow direction [25]. In our study, only the $\mathrm{K}_{3}$ axes were used to determine flow directions because the $\mathrm{K}_{1}$ axes are approximately perpendicular to the dip direction of the imbrication plane in most AMS stations. 


\section{RESULTS AND DISCUSSIONS}

\subsection{Directional Data: Flow Directions and Identification of Emission Centres}

Flow-directional data suggest at first that the ignimbrite sheets originated from more than one eruptive center. Table 1 gives the orientations of $\mathrm{K}_{1}, \mathrm{~K}_{2}$ and $\mathrm{K}_{3}$ with respect to the north as declinations (azimuths) and inclinations (plunges). $E_{1-2}, E_{2-3}, E_{3-1}$ are the semi-angles of the $95 \%$ confidence ellipses around the principal susceptibility axes; their values witness the fact that $K_{3}$ (magnetic foliation pole) is generally more well-defined than $\mathrm{K}_{1}$ (magnetic lineation), as can be seen also in the lower hemisphere projections for each analyzed site presented in Fig. (7). Comparison of $K_{1}$ and $K_{3}$ eigenvectors at specific sites and as an overall pattern provides the basis for estimating overall transport directions for each ignimbrite deposit. The definition of the direction and the sense of the flow by AMS in pyroclastic deposits is not always obvious [10]. Commonly, the flattening (magnetic foliation) of the AMS ellipsoid is parallel to the stratification (or layering), and the elongation of the ellipsoid (magnetic lineation) is parallel to the flow direction (Fig. 7). Trends of magnetic fabrics vary between each ignimbrite sheet, but are relatively well defined in some cases (Fig. 7). Based on the orientation of the principal axes $\mathrm{K}_{1}$ and $\mathrm{K}_{3}$ [26], the AMS fabrics of the sheets can be classified into: (i) normal fabrics in which $\mathrm{K}_{1}$ axis dips at angle of less than $30^{\circ}$, whilst $\mathrm{K}_{3}$ axis is nearly vertical or steeply plunging (i.e. the magnetic foliation is subhorizontal), and (ii) inverse fabric in which $\mathrm{K}_{1}$ dips at high angle (generally $>50^{\circ}$ ), whilst $K_{3}$ is subhorizontal (i.e. the magnetic foliation is subvertical). Normal fabrics may correspond to two different situations [27]: in some cases, $K_{1}$ is consistent with the flow direction inferred from the foliation imbrication, whereas in other cases it is normal to the flow direction (Fig. 8a). Such a transverse-to-flow position of $\mathrm{K}_{1}$ is rather common in ignimbrites. Therefore, $K_{3}$ is preferred to $K_{1}$ to derive flow direction in ignimbrites, a situation that is different from the case of other magmatic rocks [28]. More precisely, the sense of transport is based on the imbricated pattern of magnetic foliations, provided that the paleotopography is either recognized in the field (sites GM1, GM31, GM35 and GM36) or assumed with respect to the source. In the case of inverse fabrics, no flow direction can be deduced from the magnetic data. Fig. (7) presents the AMS results at the formation level, with mean site data plotted on the map and

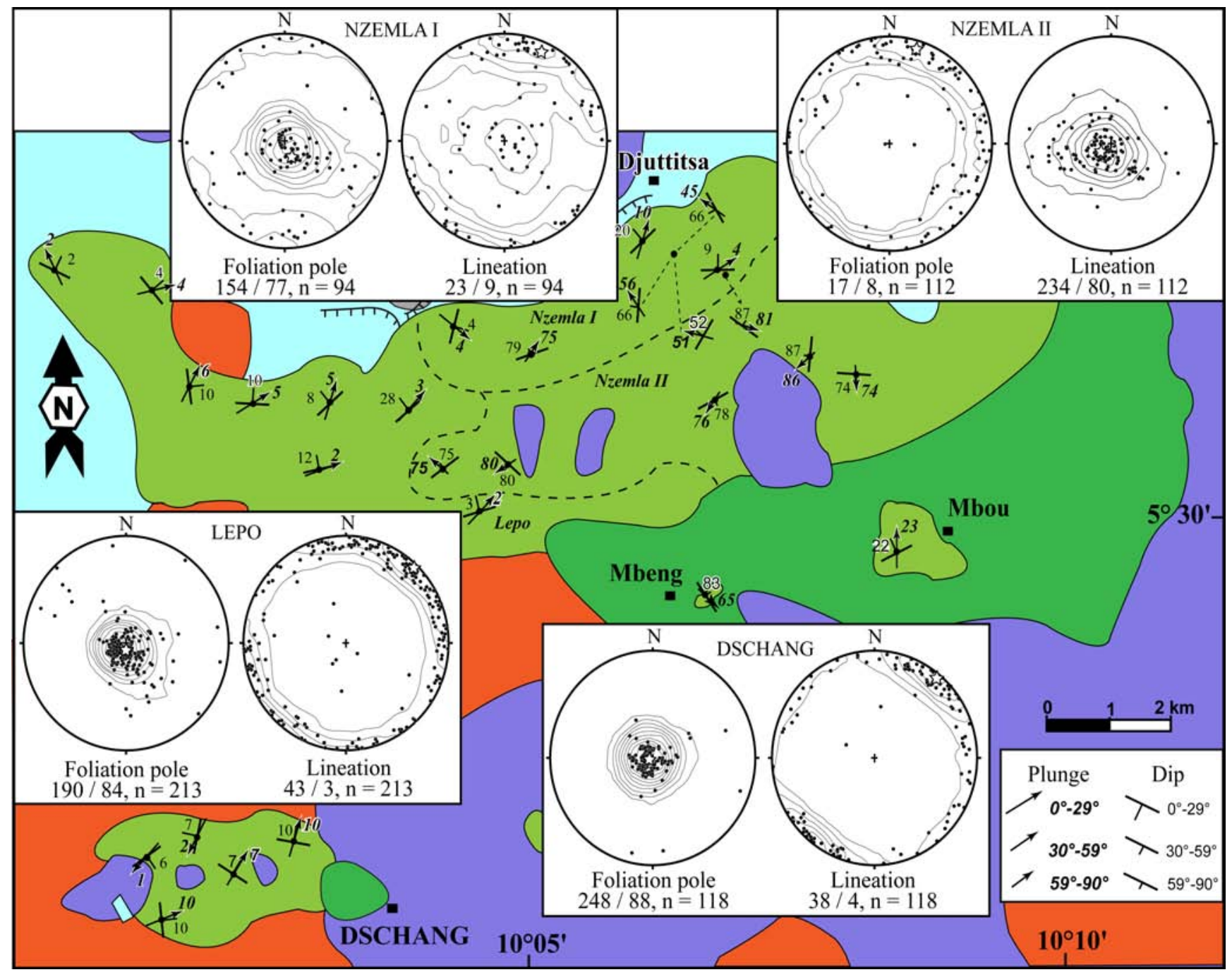

Fig. (7). Magnetic foliation and magnetic lineation map obtained for accepted AMS stations from Mount Bambouto ignimbrites. Projection diagrams for foliation poles and lineation are also shown. 

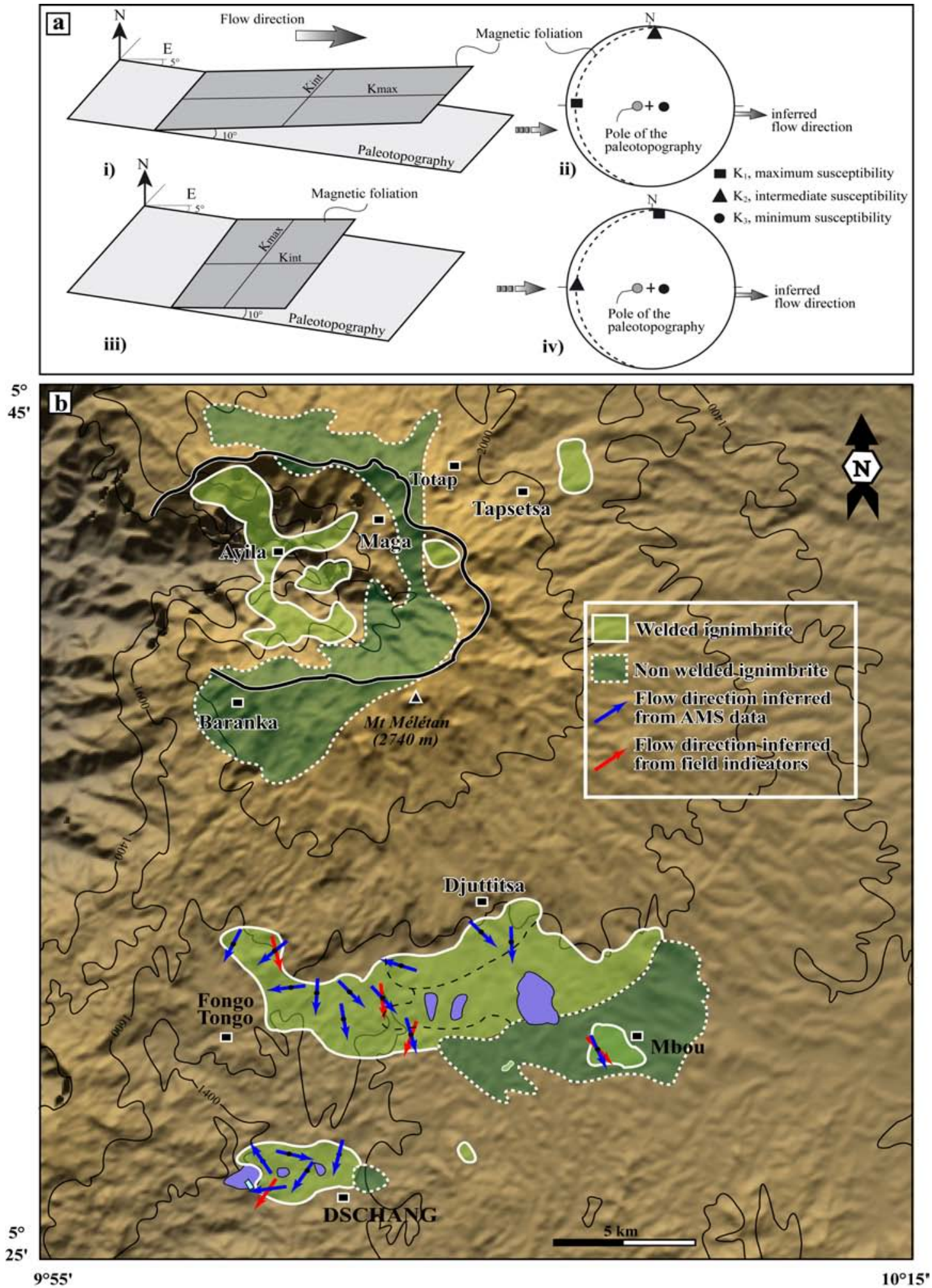

Fig. (8). a) Conceptual model for imbrication of magnetic foliation in two ideal cases; (i) Magnetic foliation can be imbricated with Kmax axis oriented parallel and (ii) perpendicular to the flow direction, and the related (iii, iv) stereoplots of AMS axes. Note the orientation of the magnetic foliation is parallel to the inferred flow direction in both cases (redraw from Giordano et al., 2008 [27]). b) Map showing mean flow directions inferred from the orientation of AMS ellipsoids and from field indicators.

all sample data plotted in the lineation and foliation pole synthetic diagrams. Flow directions for each site characterized by a normal fabric are plotted in Fig. (8b).
All stations of Dschang ignimbrites present normal fabrics. Magnetic lineations (best line at 38/4; Fig. 7) have low plunges $\left(1\right.$ to $\left.10^{\circ}\right)$ and generally define a NE-SW axis. The magnetic foliations have a best pole at 248/88 (Fig. 7). 
For three of these sites (GM1, GM2, GM3), magnetic foliation planes dip range from $7^{\circ}$ to $10^{\circ} \mathrm{NE}$ with a magnetic lineation consistent with the flow direction inferred from $\mathrm{K}_{3}$. For the remaining two stations (GM4, GM5), magnetic foliations dip very gently $\left(6^{\circ} \mathrm{SE}\right.$ and $\left.7^{\circ} \mathrm{SSE}\right)$ with $\mathrm{K}_{1}$ perpendicular to the imbrication of $\mathrm{K}_{3}$ axes. The general flow direction at Dschang ignimbrites (sites GM1, GM2, GM3), inferred by magnetic data and field indicators (imbricated fiammes around site GM1) suggest that flow was directed towards SW (Fig. 8b). The AMS data for the remaining two stations (GM4 and GM5) are nearly orthogonal to the general trend. We infer that change in the flow imbrications angle and $\mathrm{K}_{1}$ directions across the area reflect variations in local slope which increases the overall dispersion of the transport data. Indeed, the effect of subtle topography on AMS directional data has been recognized in other ignimbrites (e.g., [29-31]).

AMS stations at Lepo show synthetic stereograms with a best pole of magnetic foliation at 190/84 and a best line of magnetic lineation at $43 / 3$ (Fig. 7). All stations present normal fabrics and yield readily interpretable AMS directional data. Three sites (GM36, GM37 and GM38) have magnetic foliation planes gently inclined $\left(2-10^{\circ}\right)$ to $\mathrm{NE}$, while site GM35 display $\mathrm{K}_{3}$ axe inclined $\left(10^{\circ}\right)$ approximately to E. The four remaining sites (GM13, GM14, GM15, GM17) are imbricated to the NW $\left(3-28^{\circ}\right)$, as can be seen in Fig. (7). Magnetic lineations generally present a NESW direction with low plunges $\left(2\right.$ to $6^{\circ}$ ). At Lepo, except for site GM35 with an approximately E-W flow direction, AMS and field transport directions clearly show that the emission centre of this pyroclastic flow is situated north of this area, which is the position of the Bambouto Caldera (Fig. 8b).
Eight AMS sites at Nzemla I display $\mathrm{K}_{1}$ and $\mathrm{K}_{3}$ axes somewhat dispersed with a general concentration respectively trending to the NW and SE (best pole of magnetic foliation at 154/77 and best line at 23/9; Fig. 7). In detail, 3 sites display normal fabrics with gently inclined magnetic foliation planes (best foliation poles at 283/86, 179/81 and 139/70 for GM18, GM7 and GM34, respectively) and subhorizontal lineations. These 3 stations suggest a poorly defined transport direction toward a sector from the south-east to the west, consistent with field data indicating transport toward the south-west at site GM 7. The remaining 5 stations which display inverse fabrics with steeply dipping foliation planes $\left(52-87^{\circ}\right)$ and moderately to highly plunging lineations $\left(45-81^{\circ}\right)$. In the whitish units, only one AMS site at Mbou (GM11b with a normal fabric) was used to infer the flow pattern in this locality: the magnetic foliation pole points to the northwest, sugesting a NW to SE flow. At these localities, excepted site GM18 (with anomalous ESE-WNW transport direction, certainly also due to variation of local topography), general flow direction inferred from AMS is to SE (Fig. 8b), consistent with flow direction infer from field indicators (imbricated lithic fragments) around station GM11. Thus, magnetic fabric and field indicators also evidently indicate Bambouto Caldera as source area in the NW of these localities (Fig. 8b).

At Nzemla II, Mbeng and Baranka, because of the vertical magnetic fabrics, no flow direction can be recognized. The five sites of Nzemla II locality display foliation dip, which varies from $75^{\circ}$ to $87^{\circ}$ and plunges of lineation from $51^{\circ}$ to $86^{\circ}$. At the Mbeng locality, site GM10 also shows inverse fabric with a subvertical foliation plane

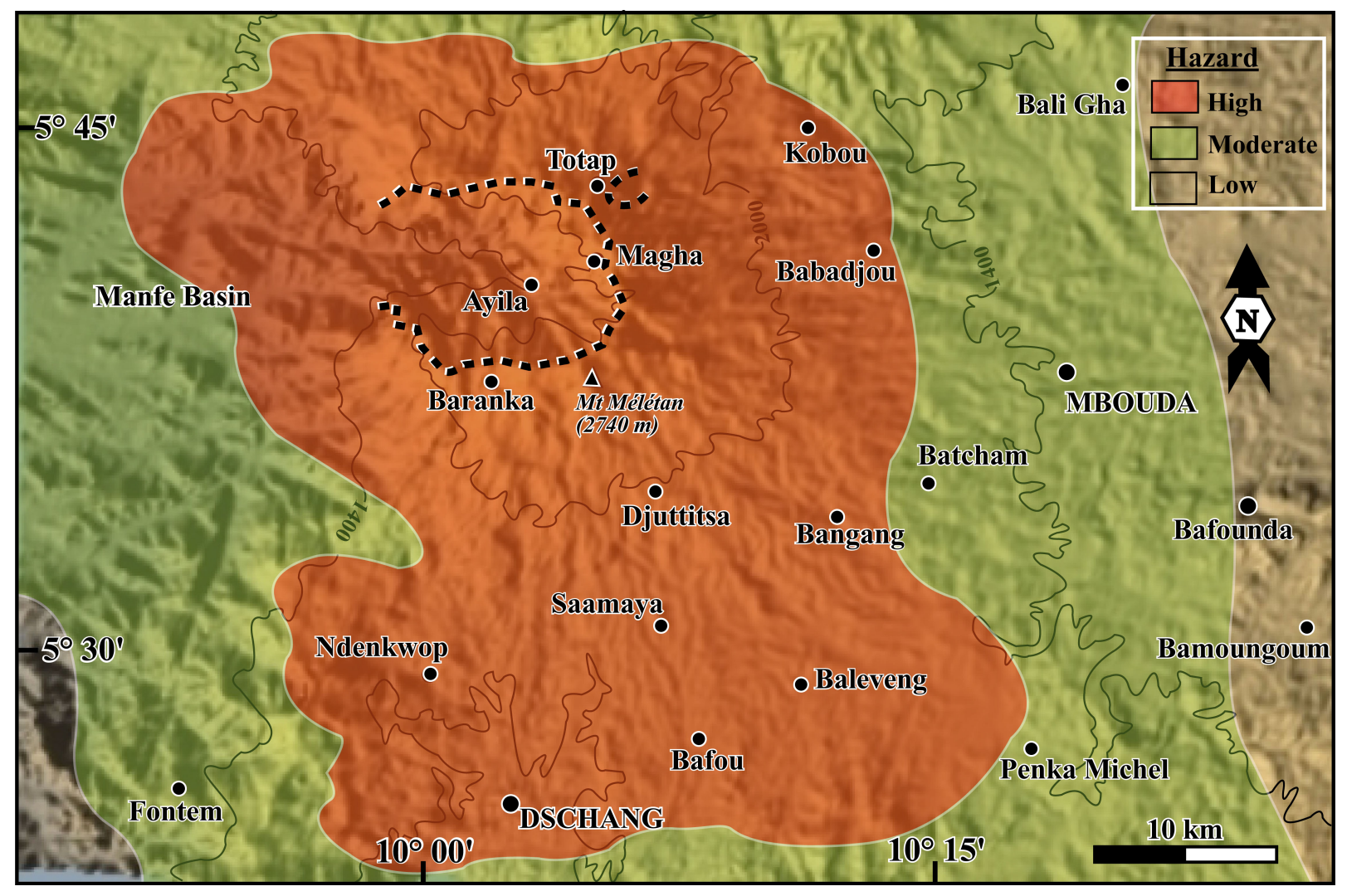

Fig. (9). Hazard map of ignimbritic eruption of Mount Bambouto. 
Table 1. Magnetic Data of Mount Bambouto

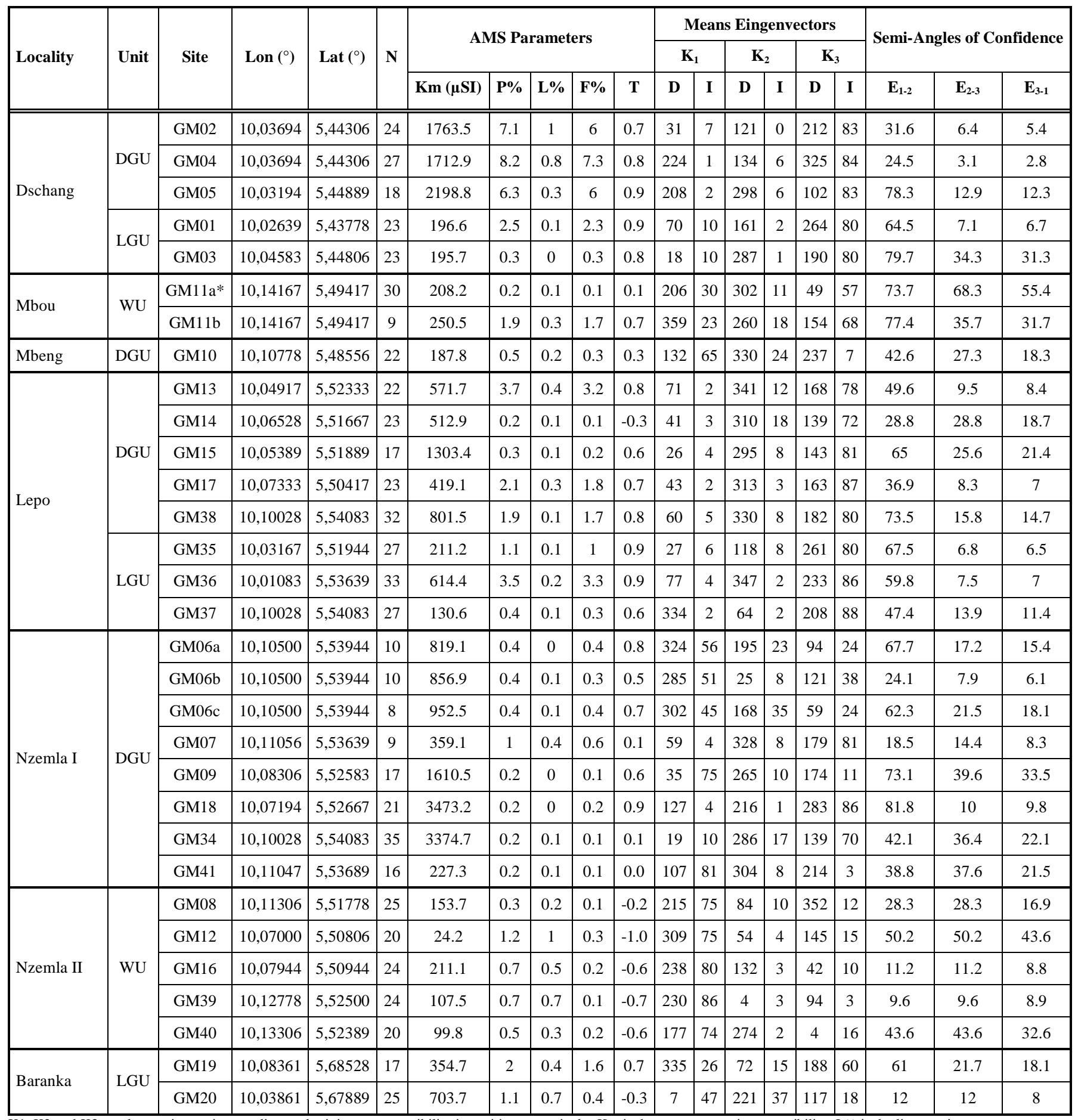

$\mathrm{K} 1, \mathrm{~K} 2$ and $\mathrm{K} 3$ are the maximum, intermediate and minimum susceptibility intensities respectively; Km is the mean magnetic susceptibility; L\% is the linear anisotropy percentage; F\% is the planar anisotropy percentage; P\% is the total anisotropy percentage; $\mathrm{T}$ is the Jelinek's shape parameter [9]; $\mathrm{D}$ : declination in degrees; $\mathrm{I}$ : inclination in degrees; $\mathrm{N}$ is the number of samples for the site; E1-2, E1-2, E1-2 are semi-angles of the 95\% confidence ellipses around the principal susceptibility axes;

* Sample with star represent rejected sample due to high within site dispersion.

$\left(83^{\circ}\right)$ and a high plunge of lineation $\left(65^{\circ}\right)$. In Mount Bambouto Caldera, ignimbrites outcrop at Baranka; station GM20 displays a subvertical foliation with moderate plunge of magnetic lineation of $47^{\circ}$ to the north. Station GM19 shows a moderately dipping magnetic foliation (pole at 188/60) and a transverse-to-flow magnetic lineation (trending at 335/26).
Finally, based on imbrication of magnetic foliation and field indicators, we conclude that the pyroclastic density current responsible for these ignimbrites was generated from Mounts Bambouto caldera. The eruption and emplacement of these ignimbrites was made in multiple phases because of different age of deposits. 
Table 2. Average Construction Costs in the Mount Bambouto Region (Updated in 2011)

\begin{tabular}{|c|c|}
\hline Type of Construction (Houses and Roads) & Cost per $\mathbf{~}^{2}$ of Housing and Road (FCFA). (1,000 FCFA = \$US2.2) \\
\hline \hline Wooden or clay-brick cabin without foundations & $20,000-30,000$ \\
\hline Wooden or clay-brick cabin on a masonry foundation & $40,000-55,000$ \\
\hline Mixed construction building (breeze-blocks and wood or sheet metal) & 70,000 \\
\hline "Standard"' house of breeze-blocks and reinforced concrete (R0-R1-R2-R3) & 130,000 per storey \\
\hline Road & Tarred: 2500 ; Not tarred: 500 \\
\hline
\end{tabular}

\subsection{Mapping and Assessment of the Ignimbritic Hazards}

\subsubsection{Mapping}

With the help of an outcrop map of exposed ignimbrites at Mount Bambouto and their thickness, we have realized a hazard map (Fig. 9) related to pyroclastic flow or ignimbritic eruption responsible for these deposits. The region of high risk corresponds to: (i) zone where the ignimbrites are thick; and (ii) where highly sloping topography area would facilitate the displacement of pyroclastic currents. The region of moderate and low risk corresponds to areas where there are no ignimbritic deposits or zones of less thick deposits. In the areas where ignimbrites are covered by younger rocks, the boundary of pyroclastic deposits was estimated from multiple quarries (for construction or engineering materials), wells and especially from water drillings (for domestic use), carried out on basaltic covers. It should be noted that the areas where the basalt outcrops are densely populated zones because of soil fertility. The drillings made in these areas are in significant numbers (over 120 listed) and deeper than 45 meters in most cases. The data collected (thickness of pyroclastic deposits) have permitted a more realistic estimation of the surface, the volume of ignimbrites and reliable hazard map.

\subsubsection{Risk Assessment}

The Mount Bambouto volcano and its close surrounding are densely populated with approximately 450,000 inhabitants. The information for the inventory and location of the exposed elements, followed by the analysis of the different values (human, social, monetary, economic, strategic, and environmental) was obtained from the relevant Cameroonian government departments and concerned organizations by field surveys. The elements considered by the Cameroonian authorities as being the most important are:

- population (urbanized areas and sites of periodic concentrations of people, such as schools, main centres of worship, markets, and stadiums);

- strategic buildings for crisis management (governance, army and security, and health centres);

- buildings, infrastructures and networks (housing, water-supply systems, power networks, roads and bridges, and telecommunications relays);

- natural environment and farmland (vegetation and hydrography, food crops, and industrial plantations);

- main centres of economic and financial interest (banks, factories, and tourist centres).
Assessing the value of the different elements-at-risk was based on information obtained from the various services and organizations responsible for the social system (Table 2). It is thus possible to assess by this method of calculation the total capital budget (updated to 2011) of the different elements-at-risk within the study area at about 950 billion Fcfa or \$US2.1 billion.

\section{CONCLUSIONS}

AMS is a good tool for the determination of flow directions in initially hot volcanic deposits and specifically in deposits of pyroclastic density currents, which are generally isotropic in most outcrops. The high density of population in the Mount Bambouto region $(450,000$ inhabitants) increases the level of risk from future explosive eruptions. This type of study could be extended in this massif on other volcanic products such as basalt, trachyte and rhyolite which cover about $75 \%$ of Mount Bambouto in order to realize a reliable hazard map. The AMS study will also very helpful in Mount Cameroon (where the last eruptions occurred in 1999 and 2000) in order to refine the hazard zoning map realized at that massif [32].

\section{CONFLICT OF INTEREST}

The authors confirm that this article content has no conflicts of interest.

\section{ACKNOWLEDGEMENTS}

This work was stimulated by numerous discussions with the late Professor Nono Alexandre which has suddenly deceased on the morning of 24 July 2012; our posthumously thanks are addressed to him. We also thank anonymous reviewers for their constructive comments and suggestions for the improvement of the manuscript.

\section{DISCLOSURE}

Part of information included in this paper, which constitute the continuation of previous work of Gountié Dedzo et al. (2011), has been previously published in Journal of Volcanology and Geothermal Research Volume 203, Issues 3-4, 15 June 2011, Pages 113-132.

\section{REFERENCE}

[1] Dongmo KA, Nkouathio DG, Pouclet A, et al. The discovery of Late Quaternary basalt on Mount Bambouto: implications for recent widespread volcanic activity in the southern Cameroon Line. J Afr Earth Sci 2010; 57: 87-108.

[2] Dedzo GM, Nédélec A, Nono A, et al. Magnetic fabrics of the Miocene ignimbrites from West-Cameroon: implications for pyroclastic flow source and sedimentation. J Volcanol Geotherm Res 2011a; 203: 113-32. 
[3] Tefogoum ZG, Nkouathio DG, Dongmo KA, Dedzo GM, Tchoua FM. Mont Bambouto Caldera (Cameroon Volcanic Line): structure and environmental impact. YES symposium in conjunction with the 23rd Colloquium of African Geology, Johannes Burg, South Africa, January 8-14, 2011; p. 452.

[4] Tefogoum ZG, Dongmo K, Nkouathio DG, Wandji P. Typology of natural hazards and assessment of associated risks in the Mounts Bambouto Caldera (Cameroon Line, West-Cameroon). Acta Geol Sin 2009; 5: 1008-16.

[5] Branney MJ, Kokelaar P. Pyroclastic density currents and the sedimentation of ignimbrites. Geol Soc. London: Memoirs 2002.

[6] Youmen D, Schmincke HU, Lissom J, Etame J. Données géochronologiques : mise en évidence des différentes phases volcaniques au Miocène dans les monts Bambouto (Ligne du Cameroun). Sci Technol Dev 2005; 11: 49-57.

[7] Nkouathio DG, Dongmo KA, Bardintzeff JM, Wandji P, Bellon H, Pouclet A. Evolution of volcanism in graben and horst structures along the Cenozoic Cameroon Line (Africa): implications for tectonic evolution and mantle source composition. Mineral Petrol 2008; 94: 287-303.

[8] Dedzo GM, Nono A, Njonfang E, et al. Le volcanisme ignimbritique des Monts Bambouto et Bamenda (Ligne du Cameroun, Afrique Centrale): signification dans la genèse des caldeiras. Bull Inst Sci Rabat (Maroc), Section Sciences de la Terre 2011; 33: 1-15b

[9] Jelinek V. Characterization of the magnetic fabric of rocks. Tectonophysics 1981; 79: 563-7.

[10] Ellwood BB. Estimate of flow direction for calc-alkaline welded tuffs and paleomagnetism data reliability from anisotropy of magnetic susceptibility measurements: central San Juan Mountains, southwest Colorado. Earth Planet Sci Lett 1982; 59: 303-14.

[11] Knight MD, Walker GPL, Ellwood BB, Diehl-Jimmy F. Stratigraphy, paleomagnetism and magnetic fabric of the Toba tuffs; constraints on the sources and eruptive style. J Geophys. Res 1986; 91: 10355-82.

[12] MacDonald WD, Palmer HC. Flow directions in ashflow tufts: a comparison of geological and magnetic susceptibility measurements, Tshirege member (upper Bandelier Tuff), Valles Caldera New Mexico, USA. Bull Volcanol 1990; 53: 45-59.

[13] Seaman SJ, Mcintosh WC, Geissman JW, Williams ML, Elston WE. Magnetic fabrics of the Bloodgood Canyon and Shelley Peak Tuffs, south-western New Mexico: implications for emplacement and alteration processes. Bull Volcanol 1991; 53: 460-76.

[14] Wolff JA, Ellwood BB, Sachs SD. Anisotropy of magnetic susceptibility in welded tuffs: application to a welded-tuff dyke in the Tertiary Tram-Pecos Texas volcanic province. USA, Bull Volcanol 1989; 51: 299-310.

[15] Palmer HC, MacDonald WD. Anisotropy of magnetic susceptibility in relation to source vents of ignimbrites: empirical observations. Tectonophysics 1999; 307: 207-18.

[16] Rochette P. Magnetic susceptibility of the rock matrix relate to magnetic fabric studies. J Struct Geol 1987; 9: 1015-20.

[17] Rochette P, Jackson M, Aubourg C. Rock magnetism and the interpretation of anisotropy of magnetic susceptibility. Rev Geophys 1992; 30(3): 209-26.

[18] Tarling DH, Hrouda F. The magnetic anisotropy of rocks, Capman and Hall: London 1993; p. 217.

[19] Bouchez JL. Granite is never isotropic: an introduction to AMS studies of granitic rocks. In: Bouchez JL, Hutton DHW, Stephens WE, Eds. Granite: from segregation of melt to emplacement fabrics. Kluwer: Dordrecht 1997; pp. 96-112.
[20] Hillhouse JW, Wells RE. Magnetic fabric, flow directions, and source area of the lower Miocene Peach Springs Tuff in Arizona, California, and Nevada. J Geophys Res 1991; 96: 12443-60.

[21] Ort MH. Eruptive processes of caldera formation in a nested downsag-collapse caldera: Cerro Panizos, central Andes Mountains. J Volcanol Geotherm Res 1993; 56: 221-52.

[22] Le Pennec JL, Chen Y, Diot H, Froger JL, Gourgaud A Interpretation of anisotropy of magnetic susceptibility fabric of ignimbrites in terms of kinematic and sedimentological mechanisms: An Anatolian case-study. Earth Planet Sci Lett 1998; 157: $105-27$.

[23] Henry B. Contribution à l'étude des propriétés magnétigues de roches magmatiques des Alpes: conséquences structurales, régionales et générales Trav Lab Tectonphysique. CRE: Paris 1980; vol. 80/07: pp. 1-528.

[24] Thompson R, Oldfield F. Environmental magnetism. Allen and Unwin: London 1986; p. 227.

[25] Alva-Valdivia LM, Rosas-Elguera J, Bravo-Medina T, et al. Paleomagnetic and magnetic fabric studies of the San Gaspar ignimbrite, western Mexico: constraints on emplacement mode and source vents. J Volcanol Geotherm Res 2005; 147: 68-80.

[26] Wang X, Roberts J, Schmidt P. Flow directions of carboniferous ignimbrites, southern New England Oregon, Australia, using anisotropy of magnetic susceptibility. J Volcanol Geotherm Res 2001; 110: 1-25.

[27] Giordano G, Porreca M, Musacchio P, Mattei M. The Holocene Secche di Lazzaro phreatomagmatic succession (Stromboli, Italy): evidence of pyroclastic density current origin deduced by facies analysis and AMS flow directions. Bull Volcanol 2008; 70: 122136.

[28] Bouchez JL. Anisotropie de susceptibilité magnétique et fabrique des granites. CR Acad Sci Paris 2000; 330: 1-14.

[29] Buesch DC. Incorporation and redistribution of locally-derived lithic fragments within a pyroclastic flow. Geol Soc Am Bull 1992; 104: 1193-207.

[30] Ort MH, Orsi G, Pappalardo L. Anisotropy of magnetic susceptibility studies of depositional processes in the Campanian Ignimbrite, Italy. Bull Volcanol 2003; 65: 55-72.

[31] Petronis MS, Geissman JW. Anisotropy of magnetic susceptibility data bearing on the transport direction of mid-tertiary regional ignimbrites, Candelaria Hills area, West-Central Nevada. Bull Volcanol 2008; 69: 930-51.

[32] Thierry P, Stieltjes L, Kouokam E, Nguéya P, Salley PM. Multihazard risk mapping and assessment on an active volcano: the GRINP project at Mount Cameroon. Nat Hazards 2008; 45: 42956.

[33] Ngako V, Njonfang E, Aka TF, Affaton P, Nnange MJ. The NorthSouth Paleozoic to Quaternary trend of alkaline magmatism from Niger-Nigeria to Cameroon: complex interaction between hotspots and Precambrian faults. J Afr Earth Sci 2006; 45: 241-56.

[34] Lee DC, Halliday AN, Fitton JG, Poli G. Isotopic variations with distance and time in the volcanic islands of the Cameroon Line: evidence for a mantle plume origin. Earth Planet Sci Lett 1994; 123: 119-38.

[35] Ballentine CJ, Lee DC, Halliday AN. Hafnium isotopic studies of the Cameroon Line and new HIMU paradoxes. Chem Geol 1997; 139: 111-24.

[36] Gouhier J, Nougier J, Nougier D. Contribution à l'étude volcanologique du Cameroun («Ligne du Cameroun»-Adamawa), 17. Ann Fac Sci Univ, Yaoundé Cameroun 1974; pp. 3-48.

[37] Tchoua FM. Sur l'existence d'une phase initiale ignimbritique dans le volcanisme des Mounts Bambouto (Cameroun). C R Acad Sci Paris 1973; 276: 2863-6.

This is an open access article licensed under the terms of the Creative Commons Attribution Non-Commercial License (http://creativecommons.org/licenses/by$\mathrm{nc} / 3.0 /$ ) which permits unrestricted, non-commercial use, distribution and reproduction in any medium, provided the work is properly cited. 